Dr. Steve Cooke, smc77@le.ac.uk, pre-publication draft, please do no cite or circulate without permission.

\title{
Cosmopolitan Disobedience
}

On September $18^{\text {th }} 2013$ two Greenpeace activists, protesting against oil drilling in the Arctic, attempted to climb a Russian oil rig in order to hang a banner from it. The protest was conducted peacefully and preceded by an announcement on social media. The two activists were captured and detained by the Russian coastguard. The following day, Russian security forces boarded the activists' ship, the Arctic Sunrise, and detained the ship's crew, a freelance journalist, and more activists. In total, thirty people were taken at gunpoint, beaten, and imprisoned. They became known as the Arctic 30. The Arctic 30 spent two months in jail. Initially, they were charged with piracy - carrying a fifteen-year maximum sentence - although this charge was dropped after international outcry and replaced with one of aggravated hooliganism, carrying a maximum term of seven years. All thirty prisoners were eventually released and granted amnesty following pressure from governments and civil society. Nine months after it was seized, the Arctic Sunrise was also released.

The case of the Arctic 30 is an example of a trend towards increasingly global forms of protest. Protesters from across the globe routinely join together to practice their activism across borders. Many of these protests are addressed at issues that are global or international in nature such as climate change or international finance regimes. When world leaders gather each year for the Conference of the Parties (COP) to the United Nations Framework Convention on 
Climate Change they are met by environmental protesters from around the world. Similarly, when members of the World Economic Forum meet so too will they be greeted by anti-capitalist and anti-globalisation protesters. Others speak to more localised cross-border issues such the case in 2018 when activists from Spain, France, Germany, Holland and Italy gathered near the French border in the Italian town of Ventimiglia to protest against policies preventing migrants entering Europe from North Africa via the Mediterranean. But there are also cases where protesters cross borders to protest the ostensibly domestic issues of another nation. For example, in the USA, 2016-18 protests against the local impact on the regional water supply and sites of spiritual importance resulting from the construction of the Dakota Access Pipeline drew in First Nation and other environmental activists from Canada. Finally, foreigners are often participants in protests within the nation they reside in. A good example of this is the case of protests against attacks on the Central European University (CEU) in Hungary by the increasingly authoritarian government of Victor Orban. These protests in 2017 and 2018 included thousands of international students and academics resident in Hungary for the purposes of work or study.

These forms of transnational and global protest create interesting issues for political morality, particularly when they involve deliberate breaches of law. To date, most ethical consideration of illegal protest has been conducted in the context of a citizen's relationship with her state and her fellow citizens within that state. As a result, challenging problems raised by the issue of foreign non-state 
actors engaging in protest have been largely overlooked. This problem is one identified in recent a paper by Siobhan O'Sullivan, Care McCausland, and Scott Brenton. In their paper they try to determine if anti-whaling activities on the high seas and other forms of illegal transnational animal rights activism can be described as civil disobedience using a Rawlsian understanding of the concept. The focus of their attempt is to ask if acts such as those of Sea Shepard and Greenpeace conform to the requirements of being conscientiously motivated, carried out in public, aimed at changing the law, and non-violent. In the course of their analysis they highlight the link between the Rawlsian conception of civil disobedience and the nation state, noting that his conception defines civil disobedience as a means by which citizens challenge the laws of their own states. This, they note, leaves the conception ill-equipped to address contemporary forms of activism and the existence of transnational law. They conclude with a call to re-conceptualise civil disobedience in a way that connects it with notions of global citizenship. ${ }^{1}$ This paper is an attempt to answer that call and address some of the wider issues raised by the practice of transnational disobedience.

One interesting attempt to address this gap has recently been made by Michael Allen, who develops a standard that citizens of both liberal and non-liberal states can appeal to in order to justify conscientious law-breaking. Allen's conception of cosmopolitan civil disobedience is narrower in scope than the one I develop here, allowing only for protests against global injustice, ${ }^{2}$ and is underpinned by the

\footnotetext{
O’Sullivan, Siobhan, McCausland, Clare \& Brenton, Scott. 2017. Animal Activists, Civil Disobedience and Global Responses to Transnational Injustice. 23: 261-280.

2 Michael Allen, Civil Disobedience in Global Perspective: Decency and Dissent over
} 
concept of decency found within Rawls' Law of Peoples. ${ }^{3}$ This conception requires disobedients to appeal to shared standards of justice, supplied at the international level his reading of decency. As a result of this stipulation, Allen's conception of civil disobedience, like that of Rawls, rules out civil protests against the conception of justice itself, a problem I confront in $\S 3$. The appeal to shared standards is partly pragmatic, Allen claims that disobedience cannot be successful without shared commitments concerning justice. ${ }^{4}$ However, whilst the thought that disobedience must carry a reasonable prospect of success for it to be permissible is a plausible one, it isn't obvious that agents must first agree on upon core principles before they can be persuaded by the claims of others. For this reason, my own conception appeals to an independent standard of civility (also laid out in $\S 3$ ). Allen further restricts the scope of disobedience because he shares Rawls' prioritisation of the principle of self-determination of peoples over a liberal theory of justice. This prioritisation commits him ruling out civil disobedience addressed at the domestic politics of other states. Whilst I share Allen's concern that autonomy ought to be respected my reason is grounded in respect for personhood rather than a Rawlsian desire to maintain stability in the society of peoples. ${ }^{5}$ My response to the problem of respecting autonomy further departs from Allen's account in two important ways. First, I argue in $§ 1.1$ that civil disobedience, unlike some other forms of direct action, is persuasive in

Borders, Inequities, and Government Secrecy, Studies in Global Justice (Dordrecht, The Netherlands: Springer Netherlands, 2017), 9

3 John Rawls, The Law of Peoples, New Ed edition (Cambridge, Mass.: Harvard University Press, 2001), 62-78.

$4 \quad$ Allen, Civil Disobedience in Global Perspective, 20,25.

$5 \quad$ Rawls, The Law of Peoples, 81. 
character rather than coercive and so does not interfere with autonomy in any case. Second, I remain unconvinced that Rawls' ideal of a decent non-liberal society represents a true form of self-determination for its people not least because I affirm a human right to democratic government and a necessary condition of legitimacy authority. As an alternative to Allen's view I offer a wholehearted liberal cosmopolitanism that retains the ethical primacy of individuals and their interests rather than of peoples. ${ }^{6}$

In what follows, I argue that individuals can be justified in conscientiously breaking the law in other states, and that they may do so even when laws have been legitimately constituted by the domestic polity. This argument is cosmopolitan in nature and is justified by appeal to universal standards of respect for the moral status of individuals, permitting, conscientious law-breaking in both liberal and non-liberal states. Furthermore, conscientious law-breaking by foreigners can even conform to the high normative standards and conceptual requirements necessary for it to be properly called civil disobedience. In the first section of my argument I show how a transnational protester may be justified in her actions. Second, I argue that in some cases the justification may form the basis of a moral right of transnational disobedience. Finally, I develop a cosmopolitan ideal of civility and use it to show how acts such as those of the Arctic 30 conform to requirements necessary to merit being described as civil disobedience and so acquire a normatively privileged status compared with other

\footnotetext{
$6 \quad$ In this I follow Beitz's detailed critique of Rawls laid out in Charles R. Beitz, 'Rawls's Law of Peoples', Ethics 110, no. 4 (2000): 669-96, https://doi.org/10.1086/233369.
} 
forms of protest.

\section{§1. The Justification for Transnational Disobedience}

Let me begin with a case where theorists tend to agree that a protester has a welljustified case for law-breaking. Assume that a protester acts out of conviction, that she believes a wrong is being committed and is motivated in her lawbreaking by that belief. Further assume that her belief is well-founded. The protester's law-breaking is intended to draw attention to a wrong and to give others reasons to address this wrong. In choosing to break the law, she acts in ways that are likely to succeed in highlighting her cause and that are more effective than other routes open to her. Thus far, our protester appears strongly justified in her actions. However, some theorists think more is needed for her protest to be rendered permissible. In a nearly just society the law will be largely just in its content and it will have been constituted according to just procedures. As a result, we can reasonably assume a general presumption in favour of obeying the law. Nevertheless, it may be the case that particular laws or aspects of a decision-making procedure are unjust in some manner and that these give citizens reasons to seek to change them. Notwithstanding this fact, an agent ought not normally choose lawbreaking in the first instance as their way of challenging injustice. Ordinarily, a protester ought to seek legal means as her first course of action, opting for law-breaking only when these means have been unsuccessfully exhausted. Law-breaking ought to be a last resort because there is good reason to think that the rule of law is a necessary condition of a just society and that for 
laws and procedures to be just they must embody or express the values upon which justice is presaged. This means that challenging the law threatens to undermine justice and so ought to only be done in extremis. Thus, me might add that a protester is justified in law-breaking where she is not only acting out of conviction and for well-founded good reasons, but also where she has run out of alternative options to challenge a perceived wrong.

However, whilst there ought to be a presumption that legal means to challenge injustice should be exhausted before engaging in law-breaking there are cases where this rule does not hold. Two possibilities immediately spring to mind. One is the example, famously used by Joseph Raz, of a legal strike by ambulance workers to illustrate that it is possible for an illegal violent protest to be less harmful than legal protest. ${ }^{7}$ Along these lines, we might imagine cases where taking the time to exhaust legal means of change results in greater levels of injustice. Perhaps there is ongoing or imminent wrongful harm from an unjust law that will continue for longer whilst legal challenges are brought, but which can be halted sooner through civil disobedience. A second possibility lies in the situation, described by Kimberley Brownlee, of persistent minorities:

since causes defended by a minority are often those most opposed by persons in power, legal channels may be less than wholly effective. Moreover, it is unclear when a person could claim to have reached the situation of last resort; she could continue to use the same tired legal

\footnotetext{
Raz, Joseph. 1983. The Authority of Law: Essays on Law and Morality. Oxford: Oxford University Press, 267.
} 
methods without end. ${ }^{8}$

Brownlee's argument illustrates the difference between a theoretical possibility of change versus a practicable possibility of change. In a democracy it is theoretically possible to change any law, but contingent facts about the real world: unequal power relations, social biases, cultural practices, and so forth can render that theoretical possibility unrealisable in any meaningful sense. Thus, the principle of last resort must relate to the situation an agent actually finds themselves in rather than referring to a distant ideal. The sorts of problems faced by persistent minorities prompt Rawls to argue that conscientious law-breaking can have a corrective role, mitigating against conservative bias in society in a way that is healthy for democracy rather than a threat to it. ${ }^{9}$

\section{\$1.1 The problem of sovereignty}

It is clear that the principles of justification offered above can be applied as well to the case of transnational illegal protest as they can to the case of domestic protest. That is to say, by the account so far offered transnational disobedience is justified under the same conditions as domestic disobedience. Where the cases differ potentially lies in the reasons that speak against protest. One such reason is provided by the principle of sovereignty. The principle of sovereignty forces us to question the permissibility of breaking the legitimately constituted laws of a political community that an agent is not a member of. Any of the examples I gave

$8 \quad$ Brownlee, Kimberley. 2013. Civil Disobedience. In: Zalta, Edward N., ed. The Stanford Encyclopaedia of Philosophy. http://plato.stanford.edu/archives/win2013/entries/civildisobedience/

9 Rawls, John. 1999. A Theory of Justice. Revised edition ed. Cambridge, Mass: Harvard university press, 337-7. 
in my introduction might plausibly prompt the claim that agents have no right to interfere in the affairs of another political community, that doing so interferes with the autonomy of that community's citizens and violates their right to selfdetermination. Ordinarily we conceive of the principle of sovereignty as governing interactions between states but the normative force behind it seems also to apply to the actions of non-state actors. State sovereignty describes both an immunity from interference by other states and supreme authority over members of the political community within the state's borders. Both of these rights have a moral foundation. The state's right against non-interference derives from the rights of individuals to determine the course of their own lives insofar as they do not wrongfully interfere in those of others at the same time. To interfere with the affairs of a legitimate state breaches the rights of its citizens to selfdetermination. Similarly, legitimate authority within a state depends upon respect for the rights of those subject to that authority, one of which is also the right to determine the course of one's own life. Thus it would seem that breaking the laws of another state violates the autonomy of its citizens because it represents a form of external interference aimed at altering the course of the lives of members of the domestic polis or at overriding their choices.

Without challenging the right to self-determination, two routes to overcome or avoid the sovereignty problem present themselves. One route would be to show that the fate of those protesting is bound up with the community they protest in such that they ought to have a say in its laws. A second route would be to show 
that illegal protest does not necessarily violate the right of self-determination. If either of these conditions can be met, then a significant barrier to rendering transnational disobedience impermissible would be removed. Let me begin with the first route and the idea that it would be mistaken to assume the relevant political community for cases of transnational protest is defined by national membership and the borders of the nation-state.

\section{\$1.2 The All Affected Principle}

Cosmopolitan theorists have made an argument for transnational democracy along the following lines. First, individuals should have a say in decisions that significantly affect their lives. Second, the group of individuals significantly affected by political decisions is often not determined or delimited by the borders of the state within which those decisions are taken. Therefore, the scope of democratic decision-making ought not be determined by the borders of the nation-state but by those affected by it. A recognition that state power both extends beyond its borders and affects non-citizens within its borders makes it difficult to justify delimiting the political community by traditional notions of citizenship. ${ }^{10}$ Similarly, non-state institutions of global governance project power within what would have traditionally been considered the domain of sovereign states. If it is a requirement of justice that persons are able to exert some degree of control over the laws that govern them, then all those affected by a policy or

\footnotetext{
$10 \quad$ Heater, Derek. 2002. World Citizenship: Cosmopolitan Thinking and Its Opponents. London: Continuum, 130-144; Held, David \& McGrew, Anthony. Globalization and the Liberal Democratic State. 28: 261-288.; Dryzek, John S.. Global Civil Society: The Progress of PostWestphalian Politics. 15: 101-119.
} 
law ought to have a say in its making. It is not just traditional citizens who ought to have a right to participate, but all of those over whom political power is exercised or whose important interests are wrongfully set back. Under this All Affected Principle, ${ }^{11}$ the justification for political disobedience extends naturally to permit non-citizens to illegally protest laws which significantly affect them, but over which they have say. Thus, the high levels of acid rain over Norway in the 1980s, caused by emissions from power plants in the North of England, would have provided a justification for Norwegians to illegally protest in the UK. Similarly, unfair laws targeting resident migrants (of which the list of possible examples is distressingly long) provides them with a justification for disobedient action in their host country. The All Affected Principle calls into question the assumption that the relevant community as far as self-determination is concerned is citizens of and within the nation-state, drawing the boundaries instead according to affected interests.

The All Affected Principle is not without its critics. A particularly important objection comes from David Miller in the form of the problem of circularity. Miller points out that the question of who may be affected by a democratic decision is determined by who is included in the decision-making procedure. It therefore cannot be known who ought to be included in the decision-making procedure until after the decision is taken. The only solution that retains the All Affected Principle is to expand the demos to include everyone. Miller thinks this solution undesirable on grounds that it would undermine the sense of solidarity $\overline{11}$ Goodin, Robert E.. Enfranchising All Affected Interests, and Its Alternatives. 35: 40-68. 
and shared identity necessary for a well-functioning democratic community. ${ }^{12}$ For this reason he rejects the All Affected Principle. Miller's rejection is not itself grounded in the value of democracy, but rather it is to do with establishing and maintaining the constituency necessary for democracy to function well. If the conditions necessary for a well-functioning demos (conditions he identifies with the nation state) cannot be secured under an expansive All Affected Principle then we ought to abandon the principle.

One potential reply to Miller is to show that he overstates the strength or richness of the bonds necessary for a functioning demos, or that he understates the possibility of realising them at a transnational or global level. Miller's claim is that a well-functioning demos has the following desiderata: an attitude of willingness amongst the people to reach agreements acceptable to all; shared basic convictions about public life; a sufficient level of trust that others will behave reciprocally, and grounds for believing that others will behave consistently. ${ }^{13}$ Miller thinks these desiderata are likely to be undermined in constituencies that expand beyond the nation state because of the pull of physical distance and cultural diversity. ${ }^{14}$ However, it's not clear why he thinks this is true. There seems no convincing reason why shared norms consistent with Miller's desiderata cannot exist at the global level, or why they require identification with a nation in order to function effectively. One candidate for such a set of norms is to be found in Kant's idea of the Denkungsart: the cosmopolitan mind-set. The

\footnotetext{
12 Miller, David. 2009. Democracy's Domain. Philosophy \& Public Affairs 37: 215.

13 Ibid. 208-9.

$14 \quad$ Ibid. 207.
} 
Denkungsart is a mode of thinking based on a principle of universal hospitality towards strangers, which Kant argues we should adopt when legislating actionguiding rules. ${ }^{15}$ It includes a willingness to engage openly and peacefully with outsiders, and in a spirit of acceptance of difference and otherness. This acceptance is based upon the recognition of common humanity. Because it recognises universal moral standing as starting point for deliberating on ethical principles, and because it is motivated by principles of openness and respect, the Denkungsart is able to provide the key desiderata Miller identifies. Indeed, the literature on global citizenship contains numerous examples of globally-oriented ethical principles that might provide for trust, stability, reciprocity, and the resolution of disagreements. ${ }^{16}$ Beyond the ideal, Luis Cabrera has shown, with empirical work exploring the motivation of transnational activists and their fundraisers and supporters, that there are many examples where deep feelings of universal sympathy and global sentiment can already be found. ${ }^{17}$

Alternatively, one might take the route chosen by Robert Goodin in his treatment of the problem of circularity. Goodin argues that the All Affected Principle is normatively correct, and he accepts that the only way to plausibly interpret it is as enfranchising all in a universal constituency. Nevertheless, he recognises that doing so suffers from serious feasibility constraints. With this in mind he

15 C.f. Hill, Thomas E.. Respect, Pluralism, and Justice: Kantian Perspectives, USA, Oxford University Press, 228.

16 Parekh, Bhikhu. 2003. Cosmopolitanism and global citizenship. Review of International Studies 29: 3-17.; Cabrera, Luis. 2010. The Practice of Global Citizenship. Cambridge: Cambridge University Press; Heater, Derek. 2002. World Citizenship: Cosmopolitan Thinking and Its Opponents. London: Continuum.

17 Cabrera, 128-130. 
considers possible arrangements that might approximately realise the principle in the real world. One is to give citizens of nation states the right to appeal to global governance institutions when their interests are affected by extra-territorial actors. Another is to give people rights to claim compensation when their interests are negatively affected through a system of international law. ${ }^{18}$ These 'modest approximations' don't fall foul of Miller's objections because they leave untouched existing community boundaries, instead providing corrective mechanisms where affected interests have been overlooked. If the All Affected Principle can be satisfied via corrective measures of the sort Goodin describes, then it would seem that transnational protest can perform a similar corrective role. In drawing attention to global or transnational wrongs, illegal protests by foreign actors can provide reasons for appeals to be heard, compensation to be granted, or laws to be changed.

A further problem faced by the All Affected Principle is that it the notion of affect can encompass a great deal, including those affects that are minor in impact and have little in the way of moral significance. ${ }^{19}$ It is implausible to think that the All Affected Principle requires that all ought to have a say on all decisions that affect them no matter how tiny the degree to which they are affected. Nor does the notion of affect alone justify protest because affects can be beneficial as well as detrimental. It would be wildly counter-intuitive to sanction illegal protest on grounds that an agent did not have a say in deciding to receive a benefit. In order

\footnotetext{
18 Goodin, 64-5.

$19 \quad$ Miller, 216.
} 
to address these issues different criteria for choosing how significant impacts ought to be before they fall under the All Affected Principle have been suggested. For example, Carol Gould argues that the principle ought to be restricted to where people 'are affected in their possibilities of realising their basic human rights' ${ }^{20}$ Basic rights she defines elsewhere as 'rights to the conditions that are minimally necessary for any human action whatever'. ${ }^{21}$ Meanwhile, Miller takes this problem as reason to reformulate the principle so that it is restricted to cases where decisions taken by a demos are coercive towards non-members. ${ }^{22}$ Miller's coercion principle is insufficient as a marker for determining when illegal protest becomes justified because there are a large range of serious wrongful harms that a democratic decision can result in but which are not coercive in nature. Miller takes coercion to mean applying pressure in order to force one person to act as another wills. Poisoning the atmosphere or devastating ecosystems do not fall under this definition of coercion, nor does wantonly inflicting physical harm, but each of these things serves as an appropriate justification for activism. Similarly, Gould's basic rights violation condition is far too restrictive. Whilst being prevented from realising basic rights is extremely serious, it doesn't follow from this that violating non-basic rights is not a very serious wrong. It does not seem to be the case, for example, that right of political participation in a political community is 'minimally necessary for any human action', but it is surely the

$20 \quad$ Gould, Carol. 2006. Self-Determination beyond Sovereignty: Relating Transnational Democracy to Local Autonomy. Journal of Social Philosophy 37: 54.

21 Gould, Carol C.. 2004. Globalizing Democracy and Human Rights. Cambridge: Cambridge University Press, 38.

22 Miller, 218-25. 
case that if an agent is denied that right then they have been sufficiently wronged that resistance is justified. A more plausible route to take is the condition Goodin sets for triggering the right to claim compensation or appeal to global institutions; that of having one's significant interests negatively affected. In the end, it may turn out that the set-back of interests is not wrongful, however it is often the case that it is the act of protest itself that reveals where wrongs have been committed. Thus, if we restrict justifications to cases where there is certainty over this fact then we will end up rendering impermissible many protests which only by occurring show themselves to be justified.

The arguments above respond to the charge that transnational disobedience wrongfully violates sovereignty by challenging the idea that the boundaries of political community ought to coincide with those of the nation state. An alternative approach is to reject the claim that protest necessarily violates sovereignty even if the demos is determined by citizenship of, and residency within, the nation state. Assume for the moment that the All Affected Principle is mistaken and that citizens of a nation-state have a right to collectively take decisions without interference, even if those decisions significantly affect those outside their political community. A lot hangs on how interference is conceived of here. In a broad sense interference can be conceived as any sort of meddling in the affairs of others. This is the familiar approach of the authoritarian regime or naive cultural relativist attempting to defend states against accusations of rights violations. More plausibly, we can think of interference as coercive involvement 
in people's choices. The importance of freedom to human well-being and moral autonomy means that it is pro tanto wrong to restrict it. Miller's justification for bounding the demos according to a coercion principle (above) also offers reasons for limiting the scope of transnational protest. Any act of coercion stands in need of a strong justification. In democratic states this justification is provided by the fact that it arises out of a fair decision-making procedure. Democracy respects the free and equal status of citizens by giving each a right to an equal say in the laws that govern them and an equal status under those laws. Coercion is justified in these circumstances where it arises out of the free choices of citizens deciding collectively. External inference wrongfully imposes the will of outsiders upon the demos.

This looks to be a strong argument against many forms of transnational protest (assuming they occur in a democratic state) and, at first glance, it rules out many kinds of protest. Protest involving sabotage, threats, or obstruction fall under the scope of coercive interference since they are intended to forcibly prevent or deter action. Similarly, militant or revolutionary acts intended to undermine an existing political system subvert the will of the people and are thus rendered impermissible. However, the prohibition against coercion does not rule out all forms of protest. Protests whose primary intention is to communicate condemnation or the desire to change law, policy, or social attitudes can escape this objection. When protesters breach the law in order to express their moral outrage and supply reasons that are intelligible to the constituency in which they 
protest, and they do so in ways which respect the moral status of others, then we ought to think of their acts as persuasive rather than coercive in character. Because such acts are intended to persuade rather than coerce they do not violate autonomy-based sovereignty and thus remain permissible.

We ought to remind ourselves at this point that the free and equal status of citizens does not arise from membership of a political community. It is not membership that provides the justification for democracy. Rather, it is the prepolitical status of citizens as free and equal that generates the requirement for the political community to grant participatory rights. This fact forces us to acknowledge that the free choices of citizens are limited where their decisions affect the free and equal status of those outside their community. This means that simply because a decision is taken legitimately within a democratic community does not render that decision immune from interference. Where decisions affect outsiders in ways that violate their rights or significantly sets back their important interests then they may gain a right to challenge that decision. The principle of sovereignty has built into it reciprocal respect for the sovereignty of others. This means that even if non-citizens have no right to be part of the demos when decisions affect them, they retain a right to defend themselves against wrongful harms arising out of those decisions. Where the actions of a demos violate the rights of others outside the political community then transnational protest can be thought of as a form of self- or other-defence. 


\section{\$1.3 Acting on behalf of others}

The point above is important because it highlights the fact that often times transnational protesters engage in direct action on behalf of, or in defence of, others. Environmental protesters act not just to defend their own interests, but also those of distant and vulnerable strangers and of future generations. Animal rights activists, like the example given of Sea Shepherd, act on behalf of sentient non-human animals. In his book, Cabrera details the actions of No More Deaths activists who try to protect the human rights of unauthorised migrants crossing from Mexico into the USA. These he describes as 'desert Samaritans' ${ }^{23}$ Activism on behalf of others is harder to justify by the All Affected Principle because those acting are not themselves affected or subject to a democratic deficit. Although this is an important theoretical concern, it does not seem to be the case that illegally protesting on behalf of others is a special problem of transnational disobedience. Rather, it is an issue for any theory of protest. This issue is more visible in transnational protest because existing examples often involve protesting on behalf of those who have no democratic voice: future generations, non-human animals, migrants, the environment, and so forth. These groups are unable to participate in forming the laws that affect them, either because they lack citizenship rights or because democratic mechanisms are not in place to represent their interests. ${ }^{24}$ As a consequence of this, a cosmopolitan defence of their $23 \quad$ Cabrera, ch.4.

24 Cf. Robin Eckersley (2011) Representing Nature. In A. Alonso, J. Keane, and W. Merkel (eds.), The Future of Representative Democracy (pp. 236-257). Cambridge: Cambridge University Press., Robert Garner, 'Animals and Democratic Theory: Beyond an Anthropocentric Account', Contemporary Political Theory 16, no. 4 (1 November 2017): 459-77, https://doi.org/10.1057/s41296-016-0072-0; Sue Donaldson and Will Kymlicka, 'Unruly Beasts: Animal Citizens and the Threat of Tyranny', Canadian Journal of Political Science/Revue 
interests can be made by appeal to the same democratic reasons as I lay out in the next section. Where, for example, non-human animals are unrepresented via advocates in democratic legislatures then protestors may ground a right to protest on their behalf. Furthermore, whilst groups such as nonhuman animals are often considered outside of the scope of justice, it does not seem unreasonable to argue for their inclusion. This provides a reason, discussed in $\S 3$, for departing from theories of disobedience requiring agents to appeal to principles of justice that exclude non-humans from the start.

Animal rights and environmental protests have discussed in greater depth in Alan Carter's excellent paper 'In Defence of Radical Disobedience'. In it, Carter highlights that acting in the interests of others rather than oneself is paradigmatically conscientious in nature. ${ }^{25}$ Of future generations he writes: 'there is an indeterminate class of people who cannot participate in any democratic polity we might construct. Yet we can affect that class event to the point of determining its size.' Non-human animals and future generations are, he notes, powerfully vulnerable, unable to participate in decision-making, and unable to consent to any harms we might visit upon them. ${ }^{26}$ These facts give protesters reasons to defend them and oppose any government policy that threatens them. While this does not present a special problem for transnational protest, we might

Canadienne de Science Politique 47, no. 1 (March 2014): 23-45, https://doi.org/10.1017/S0008423914000195; Alasdair Cochrane, Sentientist Politics: A Theory of Global Inter-Species Justice (Oxford, New York: Oxford University Press, 2018).

25 Carter, Alan. 1998. In Defence of Radical Disobedience. Journal of Applied Philosophy $15: 33$.

26 Carter, 37. 
worry more about cases where protesters cross borders to protest on behalf of vulnerable others who can act for themselves and may perhaps have a political voice. Here a worry concerning paternalistic interference arises. In such circumstances it seems protesters ought to be to required to secure the consent of those they act on behalf of, or that they act with a well-founded belief that their acts are welcomed. Additionally, protesters ought to be confident that by acting they will not worsen the plight of those they seek to aid, such as by prompting harsh retribution against a minority community.

\section{\$2. A right to disobedience}

One interesting upshot of applying the All Affected Principle transnational protest is that it appears to sometimes provide a stronger justification for non-nationals to protest an unjust law than citizens of the state they protest in. In The Authority of the Law, Joseph Raz argues that there is a right to engage in civil disobedience where a democratic deficit exists. He begins with the premiss that individuals have a moral right to political participation. In a liberal state, where rights of political participation are enshrined in law and relevant participatory institutional structures exist, citizens may pursue their political goals via lawful political acts. These routes to lawful participation raise the standard of justification needed to engage in illegal protest.

It is important to keep in mind that Raz limits the right specifically to civil disobedience rather than to all forms of illegal political protest in his argument. Civil disobedience describes narrow range of acts falling within the broader 
category of disobedience. Civil disobedience is a form of protest involving deliberate breach of law by agents who are driven to do so by their strongly-held moral principles, and with the intention of bringing about social or political change. An agent's strongly-held convictions give her reasons to override pro tanto duties to obey the law. Civilly disobedient acts differ from selfish or malicious criminal acts, and from other forms of conscientious law-breaking in their communicative character. Acts of civil disobedience are expressive acts of disapproval and disassociation with injustice that communicate an agent's reasons for action to her fellows. By communicating her condemnation, the agent provides reasons that not only demonstrate her sincerely held beliefs, but also provide others with reasons to address the injustice themselves. ${ }^{27}$ Civil disobedience, because of these features, describes a form of protest that can be permissible even where authority defied is largely just and thus substantially morally legitimate. Raz's argument is made the context of a largely just liberal democratic state. His account is premised on the moral equality of rational agents and the value of freedom to act autonomously in the pursuit of a citizen's life plans. The existence of equal participatory rights creates the presumption against law-breaking discussed earlier, which is grounded in respecting the status of others as equal co-authors of the rules governing the scheme of mutual cooperation. But, in illiberal states, where the right to political participation is violated, citizens gain a remedial right to engage in civil disobedience as a means of pursing their political aims. Breaching the laws of an unjust authority for

27 Brownlee, Kimberley. Features of a Paradigm Case of Civil Disobedience. 10: 337-351. 
political or social reasons is not prima facie wrong in the way that breaching justly constituted laws might be. If the state does not provide citizens with equal rights to shape the laws that govern their lives, then civil disobedience does not need a strong justification. A lack of de jure participatory rights creates a moral right to civil disobedience that fills the participatory void. ${ }^{28}$ In liberal states civil disobedience may sometimes be justified against unjust laws or public policies, but the right of participation closes off the right of civil disobedience. The consequence of this is that the disobedient agent in a liberal state may rightly be interfered with and punished for their actions by the authorities. ${ }^{29}$ The reason Raz restricts the right of disobedience to specifically civil forms rather than the whole of the class of disobedient acts is because the idea of civil disobedience has built into it respect of the rule of law and respect for one's fellows. These features mean that when a protester engages in civil disobedience she does so in a spirit that commits her to advancing justice and affirms the equal status of all citizens. Because of this, civil disobedience has a normatively privileged status conferred upon it. If a protest is civilly disobedient, rather than, for example, covert direct action, then it ought to be judged more favourably. To count as a civilly disobedient act, a protest must conform to a demanding set of requirements whose fulfilment renders it more morally permissible than other forms of political disobedience. I say more about these features in my discussion of cosmopolitan civility below. It should be clear at this point that if we accept the All Affected

$28 \quad$ Raz, Joseph. 1983. The Authority of Law: Essays on Law and Morality. Oxford: Oxford University Press, 272-5.

$29 \quad$ Ibid. 274. 
Principle then the absence of global participatory options, or of the modest approximations Goodin describes, pushes us towards concluding that the excluded affected gain a right to engage in transnational civil disobedience. Note that this may even be the case in liberal states where the domestic polis has legally protected avenues of participation and thus no right of disobedience themselves. All of this depends of course on the concept of civil disobedience being applicable to transnational cases

\section{§3. A Theory of Cosmopolitan Civil Disobedience}

There are a few hurdles in the way of being able to straightforwardly describe transnational protests as civil disobedience even if those protests are conscientious, communicative acts of law breaking intended to bring about or prevent social or political change. O'Sullivan et all briefly touch upon some of these in their paper, but with a little work they can be overcome in a way that maintains the normative core of the concept. A key problem for a global theory of civil disobedience is how to conceive of the notion of civility in a way than is not inextricably tied to the nation state. The civil component of civil disobedience trades on two meanings of the word, both of which are relevant to defining the concept. First is the use of civil as pertaining to the realm within which disobedience occurs. Second, is in reference to the attitude of civility. To develop a cosmopolitan theory of civil disobedience I need to show both that the civil realm can extend beyond the nation state and that cross-border protest can express an attitude of civility. 
Let us consider first the scope of the civil realm in which disobedience occurs.

Influential accounts of civil disobedience have theorised the concept in terms of a citizen's relationship with the state because of how the civil realm is imagined in liberal theories of justice. Analysis of the civil component of civil disobedience shows why disobedience is only considered civil when it is addressed to one's political community. In this context, the civil element of civil disobedience pertains to the public everyday business of citizens and the state. In this sense civil disobedience is conceived as a form of protest carried out by a citizen acting as a political agent in order to change the social conditions under which she lives. Through her disobedient acts, the citizen addresses her political community so as to change the rules governing it. Theories of civil disobedience within the liberal canon have been developed as part of broader theories of justice restricted to idealised conditions in a closed political communities. ${ }^{30}$ As a result, these theories have sometimes unnecessarily restricted what counts as civil disobedience to a narrow conception of the political community delimited by state borders and membership of the citizenry. A further consequence of the focus upon the rights and duties of citizens has been that resident non-citizens have been omitted from consideration.

An alternative way to think of the civil realm is along cosmopolitan lines. We can do this by calling once more upon the All Affected Principle, and using it to

30 See, for examples, Raz, Joseph. 1983. The Authority of Law: Essays on Law and Morality. Oxford: Oxford University Press.; Rawls, John. 1999. A Theory of Justice. Revised edition ed. Cambridge, Mass: Harvard university press.; Dworkin, Ronald. 1977. Taking rights seriously. London: Duckworth. 
analyse the case of the Arctic 30. Degradation of the environment by Russian oil drilling has an impact that stretches beyond Russia's borders, but non-Russians have little or no democratic control over it. Activists thus engaged in the protest in order to address a democratic deficit. When Greenpeace announced their intention to scale the Prirazlomnaya drilling platform they stated that their reasons for doing so were in order to put a stop to Arctic drilling. Greenpeace's argument was that Russian drilling causes significant harms beyond Russian borders. The Arctic Sunrise approached the Prirazlomnaya platform flying a Dutch flag, and recall that most of the crew and activists were non-Russian. We can see clearly that their protest was partly addressed to a political community of which they were not members but whose decisions affected them. In this sense, activists involved themselves in the everyday business of the Russian state in an attempt to change Russian policy despite not being Russian citizens and despite not being within Russian state borders. At the same time, the activists were also addressing the wider global community and attempting to challenge the international framework of laws which permits Arctic drilling. The nature of the contemporary interconnected world, where political power exists in multiple overlapping domains and extends beyond state borders, means that a global the civic realm now overlaps the borders of nation states. Furthermore, although the activists were not acting within the geographical confines of the civil realm of their own state, it is clear that their protest was addressed at the public everyday business of both the Russian state and of other states engaged in similar activities. Any theory which by intention or omission restricts civil disobedience to citizens 
acting within the civil or public realm of their own state is inadequate.

An overly narrow view of the civic realm assumed in theories such as that of Rawls has been compounded by unnecessarily restrictive ways of thinking about what it means to act civilly. The civil component of civil disobedience does not merely describe the domain in which the disobedience occurs, it also refers to the courteousness of the mode of the agent's conduct. Part of what separates the uncivil from the civil protest lies in the communicative character of the act. To be civil in its communicative aspect civil disobedience must also be both reasongiving and respectful. By giving reasons, the disobedient not only communicates her convictions, and demonstrates her sincerity, but she also shows her respect for her fellows as members of the moral and political community; members who will bear burdens resulting from her law-breaking.

The All Affected Principle describes a community of interest, but perhaps, as Miller argues, not a community in the richer sense of a group with a shared identity, attitudes and goals, with shared rules and norms governing social interactions. Civil disobedience might be civil not just because it occurs in the public realm, but because it is addressed to a political community in that richer sense. Perhaps the notion of civility at work describes a mode of conduct owed to those with whom we have special associative obligations derived from our membership of a national collective? In his treatment of civil disobedience Rawls writes of the bonds of loyalty and fidelity between dissenting and non-dissenting 
citizens. ${ }^{31}$ If this is true then the form of address in a civilly disobedient act could be inextricably bound up in the concept of citizenship. Civil disobedience would necessarily involve acting in a civilly in the context of a special relationship with one's political community.

Assuming we accept Rawls' claim that citizens owe one another bonds of loyalty, we still need to say a little about where those bonds come from and what they require of us before we can say that they are absent in cases of transnational protest, or that their absence precludes transnational disobedience from being civil. In liberal democratic theory civil disobedience is thought to require a special justification because, it is claimed, there is a prima facie duty to comply with the will of the majority as expressed in the law. ${ }^{32}$ Different foundations for this duty are offered, such as that it stems from a duty of fair-play to citizens sharing the burdens of obeying the law in a scheme of mutual cooperation; ${ }^{33}$ or that failure to comply puts the necessary conditions of a just society at risk by encouraging lawlessness. ${ }^{34}$ These principles of fairness, respect, and consideration for those engaged in cooperative schemes are the source the bonds Rawls describes. Where the burdens and benefits of social cooperation are unjustly distributed, an agent may be justified in engaging in civil disobedience, but they must do so in ways that remain faithful to the rule of law. By acting in ways that demonstrate that she does not place herself outside the scope of the authority of

\footnotetext{
$31 \quad$ Rawls, 330-1.

32 Raz, 273.

33 Dworkin, 207; Rawls, 330-1.

$34 \quad$ Rawls, 328.
} 
law, the agent shows that she respects the status of her fellow citizens as free and equal members of the cooperative enterprise. This is because the right of political participation gives citizens the opportunity to be part-authors of the laws governing them. Thus, the law represents (to some degree) the exercise of a citizen's autonomy in the form of self-government, and, because each citizen has (in principle) an equal say in shaping the laws that govern them, it also embodies the principle of equality. And order to treat our fellows fairly, we owe it to them not to impose undue burdens and so we must moderate our behaviour. Civil disobedience is thus made civil by the fact that it is expressed in a way that is respectful of the principle of a free and equal citizenry engaged in a mutually beneficial cooperative enterprise. Indeed, it is that principle, in protesting injustice, which civil disobedience seeks to uphold. This is what Rawls means when he argues that civil disobedience ought to be limited to matters of justice and should appeal to the public conception of justice..$^{35}$ Thus, civility here is conceived in terms of the relationship between free and equal citizens of a nationstate. The bonds of loyalty describe a duty owed to others in virtue of the fact that they act in ways embodying recognition of their fellows' moral status and that they behave in accordance with rules necessary to secure justice.

To act civilly thus involves conveying acceptance that the interests and preferences of others matter, and that they are owed reasons when those interests and preferences are overridden. A refusal to provide a justification for her actions would indicate that the agent places her moral judgement above that of the $35 \quad$ Ibid. $326-7$ and $337-8$. 
majority simply in virtue of it being her judgement, and not because it is supported by good reasons. In addition to being reason-giving, the communicative aspect of civil disobedience also conveys sentiments. These sentiments demonstrate the strength of the agent's conviction and the importance of the reasons given. Not all sentiments are civil however. Expressions of hate, disgust, threat, or malevolence make the possibility of conveying respect and sincerity remote and thus render protests uncivil. The racist who bellows abuse in a public space is not acting civilly when he does so, and nor is the anti-Semitic demagogue who publicly calls upon people to attack a synagogue, and this is true no matter whether they act in order to encourage political change and supply reasons for their beliefs. In order for sentiments to be civil, attention must be paid to their type and appropriateness. It is not that civil disobedience must be polite or deferential, or that citizens must treat one another courteously and regardless of context, ${ }^{36}$ but that respect requires paying heed to the rights of the other, acting proportionately and within the bounds demanded by the recognition of others' moral standing, and behaving in ways which fit with a sincere and conscientious attitude. Emotions such as anger and outrage are rational, warranted responses to injustice, whereas hatred carries with it hostility and an evaluative element out of keeping with the conveyance of respect. If a fellow citizen is angry with me, and they provide me with reasons for their anger that are intelligible to me, then they

\footnotetext{
$36 \quad$ There is an important difference between respecting others as in the abstract as members of the moral community and respecting them for who they are and for what they have done. Respecting the moral standing of a vicious rapist does not require being polite to them, and nor does respecting the moral standing of an unjust enemy combatant require that a soldier refrain from harming them.
} 
have given me reason and opportunity to consider how I have angered them and respond appropriately. Whereas if they express hatred of me, or they publicly wish me ill, I will be unlikely to be motivated to respond in good faith to any claims they make. Thus, these forms of address are likely to run counter to the aim of bringing political and social change and so become self-defeating. In the same vein, the methods used to engage in civil disobedience must not themselves be oppressive or seriously unjust; rather, they must conform to the attitude of civility. An illegal protest expressing race hatred enacted through the destruction of a community centre would thus fail to meet the requisite standard of civility. Civil disobedience therefore describes a public form of address, which, whilst it is illegal, nevertheless demonstrates a respectful and considerate attitude towards one's fellows.

There are reasons to sceptical that these requirements for civility preclude transnational protest from being described as civil. For one thing, the notion of civility at work is overly conservative. If civil disobedience is only civil if it seeks to address violations of the principle of a free and equal citizenship, then protests arguing that the broader conception of justice is itself unjust will be excluded from being civil disobedience. Thus, it will not be possible to engage in civil disobedience aimed at bringing non-human animals or the environment within the scope of justice. Not only that, but if civility is defined in this narrow political sense, then it will be uncivil for foreign residents such as migrants and asylum seekers to protest injustices carried out against them, even if those injustices are 
carried out by the political community they reside within, and even if their protest addresses the public conception of justice. When one considers that part of the justification for civil disobedience offered by Rawls is that it performs a useful corrective against the innate conservative bias within a society, ${ }^{37}$ it seems contrary to then build a conservative bias into the conception of civil disobedience. Furthermore, although it is possible that membership of a community generates special obligations of civility in the form of reason-giving, this does not show that transnational protest cannot be civil in much the same way. Perhaps it is so that agents do not owe the same duties of reason-giving to foreign citizens (although I shall argue below that they may well do), nevertheless nothing about this fact prevents an agent from supererogatory reason-giving in a respectful and conscientious way. It is obviously mistaken to believe that the values of equality and respect for autonomy can only be respected in a protest carried out by a fellow citizen. Foreign protesters, travelling to Israel to protest against Israel's treatment of Israelis Arabs and Palestinians conduct their protest by appealing to these very values (assuming at least some of them are sincere in their reasons), and the substance of at least some of their complaints is that Israel fails to treat these peoples according to the values they ostensibly espouse as a liberal democratic state. It is just not the case that one needs to be a citizen or a resident to appeal to the values of freedom and equality and the public conception of justice in a way that is respectful of those the protest is conducted against. Additionally, the sentimental component of civility applies in the case of

Rawls, 336-7. 
transnational protest in just the same way as it does in traditional forms of disobedience. A hate-filled transnational protest runs as counter to the aims of bringing social and political change as a hate-filled national protest. Thus, although agents may have stronger duties of civility towards their fellow citizens they are not therefore precluded from acting civilly towards non-citizens and indeed have strong reasons to do so. No conceptual reason for excluding transnational protest from being called civil disobedience arises out of its communicative nature.

In any case, the cosmopolitan will likely argue that the community to whom we owe duties of civility is not bounded by our membership of a national political community. The emergence of global movements and issues, forms of global governance, and nascent global civil societies suggest that transnational protesters may be engaged in cooperative endeavours of the sorts that Rawls thinks generate duties of loyalty and fidelity, and so the duties he describes may well also be transnational. The actions of the Arctic 30 were not merely addressed to Russia, and they were not carried out in order to protect the environment within a particular nation-state. Rather, the Arctic 30's actions were addressed to a global political community. This global political community consists of international institutions over governance, a shared (if shallow) sense of identity, and a broad civil society that not only transcends state borders, but also has political influence over ostensibly national matters. The laws permitting the Arctic drilling that Greenpeace protests against operate in the framework of an international set of 
norms and an international legal regime. It is partly for this reason that the Netherlands attempted to have the case of the Arctic 30 resolved by the International Tribunal for the Law of the Sea (ITLOS). ${ }^{38}$ For the cosmopolitan, citizenship does not merely denote a legal relationship between the individual and her state; it is first and foremost a moral relationship denoting membership of a universal moral community, of which all humans are members merely in virtue of their common moral standing. The cosmopolitan identifies with all of humanity and carries a concomitant sense of moral responsibility. The moral component of citizenship, which drives the requirement for civility as reason-giving, is also present within the cosmopolitan account of citizenship. When Greenpeace protests against ecological harms, it addresses a political community comprised of all of humanity. More than this, protesters are not merely members of an abstract universal moral community, they are also members of a global civil society. Processes of globalisation have led to an increasingly interconnected and interdependent world. One result of these processes has been the growth of international civil movements and organisations. These can be seen in protest movements, such as those against the G8 summits and environmental movements, international NGOs, global markets, international governance institutions and so forth. These social and political movements, particularly in the environmental movement, operate within a shared set of norms of behaviour and expectations, have shared interests, and at least a loose sense of collective identity. As a result, there is a very real sense in which the Arctic 30's protest is addressed to a

\footnotetext{
38 Their attempt was unsuccessful because Russia simply ignored their request.
} 
political community that stretches beyond and across state borders. In this way, transnational protest not only falls within a global or transnational civil realm, but it may also carry citizenship-based requirements of civility stemming from the bonds of loyalty and fidelity owed to the universal moral community, and to genuine community of transnational agents engaged in collective endeavours with a shared identity.

\section{Conclusion}

Let us see now where we have ended up. I have argued that illegal transnational protest can be justified where protesters have their interests negatively affected by a demos they are not members of, and also as self- or other-defence where serious wrongful harms are threatened or inflicted. In the first case protest acts as a remedial participatory right justified on democratic grounds by the All Affected Principle. In the second case the justification is provided by a violation of universal moral law. Where agents are negatively affected the decisions of a demos they are excluded from then the All Affected Principle provides for a stronger justification for transnational protest than for protest by members of the demos itself. Foreign protesters may have a right to protest where citizens only have a permission. Finally, I have argued that if we take a cosmopolitan view of the scope of the civil realm, and accept the cosmopolitan claim about universal respect for the moral status of others, then it is in principle possible for protesters to be engaged in transnational civil disobedience. Both the civil realm, and the notion of civility as an attitude of respect can be understood in cosmopolitan 
terms. Those acts of transnational protest that conform to the requirements of being called civil disobedience, such as the protest of the Arctic 30, ought to be held in higher moral regard than other forms of illegal protest and thus also ought to carry lighter punishments or penalties. 